\title{
Maskinen i verktøykassa
}

\author{
BARBRO IRENE DAHL
}

Dahl, B. I. 2020. The machine in the toolbox. AmS-Varia 61, 21-29, Stavanger. ISSN 0332-6306, ISBN 978-82-7760-187-8

\begin{abstract}
We need to address the way shifting methods in archaeology affect the knowledge of the past. The current use of rural areas for cultivation or pasture, dictates our choice of survey- and excavation methods in development-led archaeology. While the focus is placed on visibility in areas currently used as pastures, there is a tendency not to discuss what might have been removed in cultivated areas. If we let the understanding of prehistoric land use be dictated by modern land use, we risk creating two sets of knowledge of the past which appear mutually exclusive. It is crucial that material from both cultivated fields and pastures are treated as differently preserved fragments of the same archaeological phenomena. The excavation at Myklebust, Sola municipality provides an example of the challenges stemming from the application of different methodologies and interpretations due to modern land use. Regarding the long-term use of sites such as Myklebust, modern historicism provides a view of temporality which runs to the heart of the discipline. The concentrated, multi-phase, chaotic nature of archaeological remains at this site is considered key to the importance of these sites, for both past and present practices. It can take time to revise or update long-held views of the past, and of what are considered the most suitable ways of deepening our knowledge of that past. If excavation and fieldwork are to play a central part in research development, it must begin with our willingness to broaden our perspectives in terms of field practices.
\end{abstract}

Barbro Irene Dahl, Museum of Archaeology, University of Stavanger, N-4036 STAVANGER, NORWAY.

E-mail: barbro.dahl@uis.no

Keywords: archaeological methods, source criticism, long-term use, fieldwork.

\section{Praksis i nåtid og fortid}

Kildekritiske blikk på det materialet vi registrerer og graver er vesentlig innenfor arkeologi. Metodebruk bør inneha en sentral rolle i refleksjoner rundt nåtidige og fortidige praksiser. Kunnskapsbildet er i ferd med å snus opp ned etter at flateavdekking ble tatt i bruk som metode, og det er på tide å minne oss selv om potensialet for funn av velbevarte, men lite synlige, anlegg i beitemark. Vi anvender ulike metoder i dyrkamark og beitemark, og kunnskapsbildet preges i for stor grad av områdets karakter i dag. Vår kategorisering, som inndelinga i synlige versus ikke-synlige kulturminner, er først og fremst basert på bevaringsgrad som følge av jordbruksdrift i historisk tid og er blitt styrende for vår praksis. Det er ønskelig med et skifte der vi begynner å tilnærme oss beitemark mer som dyrkamark, med en mer utstrakt bruk av maskin i beitemark både ved registreringer og utgravinger. Både registreringer og utgravinger vil bli vektlagt i denne artikkelen da det er av avgjørende betydning at kulturminneforvaltninga betraktes helhetlig. Vår felles jobb er å løfte materialets vitenskapelige potensial, noe vi blant annet kan gjøre ved å se på hvordan vår kunnskap er formet av vår praksis. Hvis flere lokaliteter gis dispensasjon uten vilkår om undersøkelser, vil våre registreringer representere all tilgjengelig kunnskap om lokalitetene, noe som borger for gjennomgående diskusjoner om kunnskapstilfang på tvers av aktørene i kulturminnevernet. Metodebruk bør stå sentralt i slike diskusjoner, likeledes kildekritikk og representativitet. Dette blir enda viktigere i perioder der kulturminnevernet står overfor store omorganiseringer.

\section{To kunnskapsbilder}

Både ved registreringer og utgravinger kan vi ende opp med to kunnskapsbilder som ser ut til å utelukke hverandre hvis vi kun fokuserer på synlighet i beitemark. Hensikten bør være at kulturminner i beitemark og dyrkamark skal supplere hverandre, eller da helst at lokaliteter i beitemark utfyller kunnskap om lokaliteter i dyrkamark. Det kan ikke være slik at vi i beitemark utelater å undersøke om det kan finnes mer enn synlige 


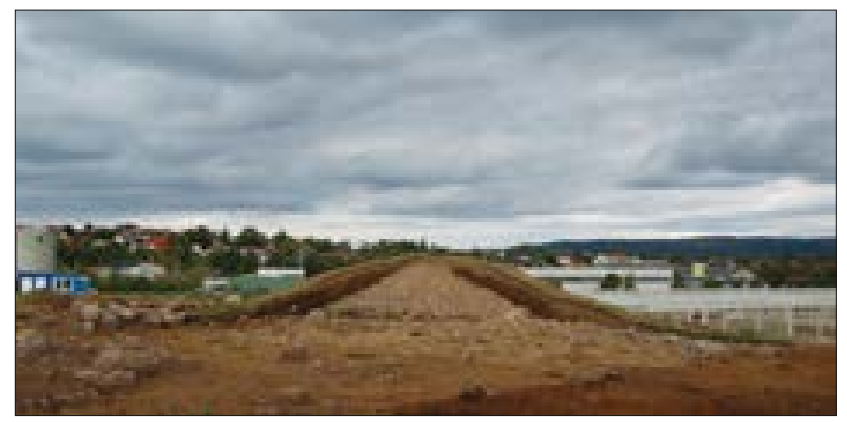

Fig. I. Avdekking av gravfelt i beitemark, Hålandsmarka i Time kommune. Foto: AM, UiS.

Fig. I. Top soil stripping of a grave field in a pasture area, Hålandsmarka, Time municipality. Photo: AM, UiS.

kulturminner, mens vi i dyrkamark utelater å diskutere om det kan ha vært synlige kulturminner. Vi kan trekke fram graver som et eksempel. Gravene vi finner bevarte spor etter i dyrkamark, må diskuteres i lys av graver i beitemark, men vel og merke helst mer enn delvise undersøkelser av gravanlegg som er synlige på dagens markoverflate (Fig. 1 og 2). Lav grad av synlighet på markoverflata kan samtidig få store utslag i forhold til vurdering av dispensasjonsspørsmålet. Dette kan eksemplifiseres ved gravfelt fra eldre jernalder i Sverige (se
Bennett, 1988, s. 22). Her ble en klar over utfordringene knyttet til den store og varierte mengden ikke-synlige kulturminner som dukket opp ved en mer systematisk totalavdekking allerede på slutten av 1960-tallet og begynnelsen av 1970-tallet (Bennett, 1985, s. 10). En viktig norsk påminner om behovet for avdekking av gravfelt er Gunnarstorp, Skjeberg i Østfold. Mens det var kjent 22 anlegg før undersøkelsene i 1955-1963, kom antallet opp i 153 anlegg ved avdekking av den sørlige delen av kulturminnefeltet som skulle benyttes som masseuttak (Wangen, 1999).

Ved avdekking av hele gravfelt kan vi ha en annen grad av sikkerhet om at de totalundersøkte gravene representerer en form for helhet, eller dette bør i det minste være noe vi streber etter å nærme oss. Et slikt materiale vil ha et langt større vitenskapelig potensial enn delvise utgravinger av enkeltliggende, synlige kulturminner. På den andre sida vil vi i dyrkamark kunne få høy frekvens av graver med gravgjemmer gravd dypt ned i undergrunnen, slik som tilfellet er i vikingtid (Dahl, 2016b). I dyrkamark vil det imidlertid være vanskelig å få innsikt i en gravskikk der begravelsene har vært anlagt i selve haugen eller røysa. Vi bør med

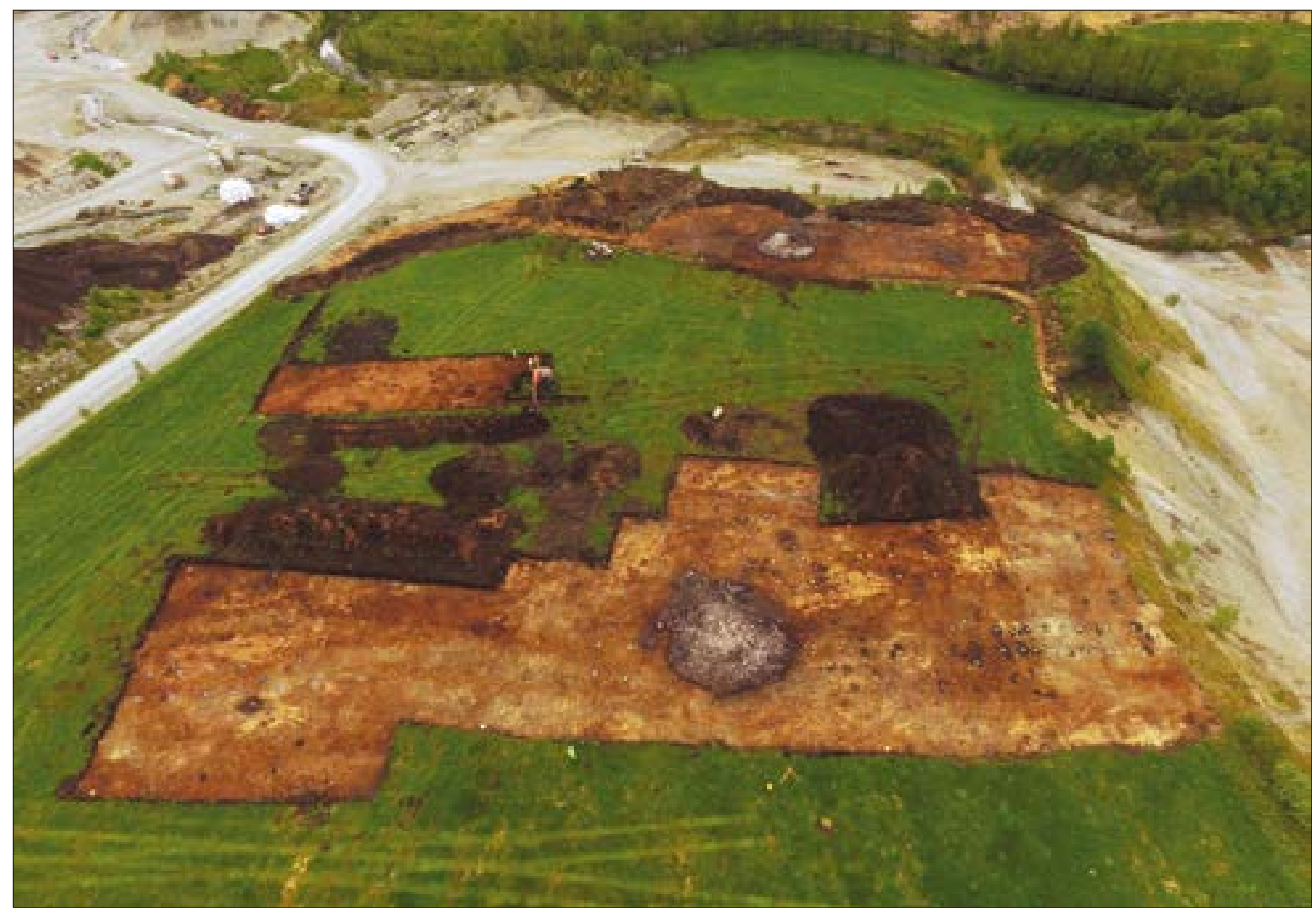

Fig. 2. Hus og gravhauger i dyrkamark på Forsandmoen, Forsand kommune. Foto: Theo G. Bell, AM, UiS.

Fig. 2. Houses and burial mounds in a farmed field in Forsandmoen, Forsand municipality. Photo: Theo G. Bell, AM, UiS. 


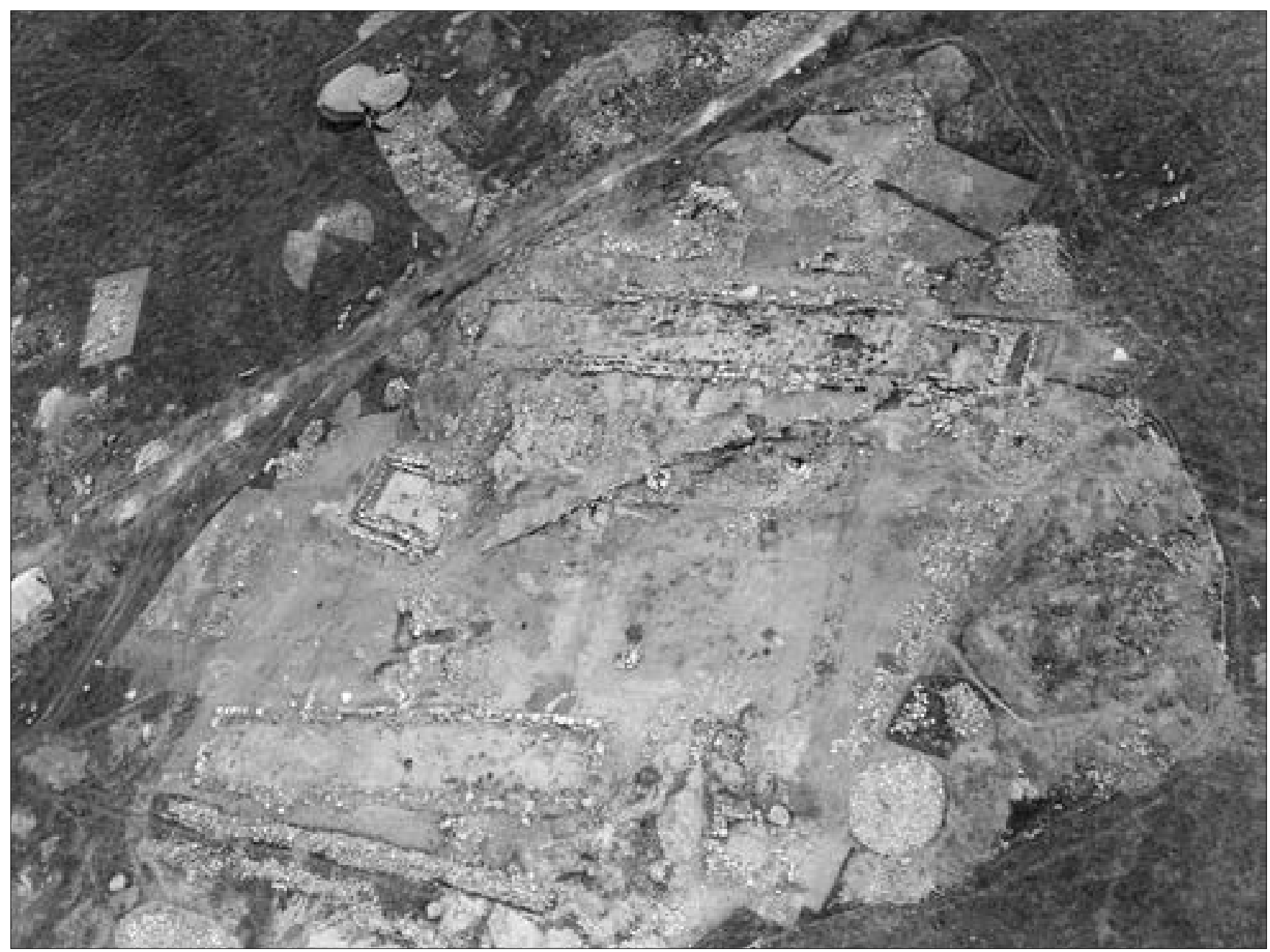

Fig. 3. Utgraving av gardsanlegget på Ullandhaug, Stavanger kommune. Foto: AM, UiS.

Fig. 3. The prehistoric farm complex in Ullandhaug, Stavanger municipality, during excavation. Photo: AM, UiS.

andre ord kontinuerlig reise kildekritiske spørsmål om representativiteten til den gravskikken vi studerer. Det er av avgjørende betydning å diskutere i hvilken grad gravskikken vi opererer med kan være formet av bevaringsforhold på undersøkelsesstedet.

De bevarte gardsanleggene i beitemark representerer uvurderlige kontekster for forståelse av materialet vi finner i dyrkamark. Utgravinger i dyrkamark vil likeledes kunne gi nye innblikk i eldre undersøkelser av gardsanlegg. Et eksempel på sistnevnte er Trond Løkens (1992, s. 41) sammenligning av de 250 bygningene som ble påvist i dyrkamark på Forsandmoen på 1980-tallet med gardsanlegget på Ullandhaug (Myhre 1980), undersøkt i beitemark på 1960-tallet. Når vi undersøker denne typen anlegg i dyrkamark, er det gjerne som om vi glemmer alle de elementer som kan ha vært over undergrunnen, det være seg ytre steinvegger eller gravhauger. Gardsanleggene er viktige påminnere om variasjonen i kulturminnekategorier, til og med når de ikke har vært avdekket, eller de har vært delvis avdekket manuelt (Myhre, 1980, Fig. 3). Vi bør minne oss selv om at det naturlige er varierte spor, en sammenblanding, enten vi kategoriserer dem som bosetting, graver eller jordbruksspor. Finnes det én type spor etter bruk av et sted, kan det hevdes at det vil være større sannsynlighet for å kunne finne flere spor etter variert bruk. Dette gjelder selvfølgelig også fra ulike tidsrom. Gardsanleggene kan igjen trekkes fram da de kan representere bruk i ulike perioder, mens vi har hatt en tendens til å se dem utelukkende som isolert til perioden yngre romertid/folkevandringstid. Generelle eksempler til å illustrere variert bruk fra mange perioder er høydedrag på Jæren der det ved større undersøkelser er påvist bygninger, graver og jordbruksspor fra tidsrommet seinneolitikum til og med vikingtid (se Børsheim \& Soltvedt, 2002; Soltvedt, Løken, PrøschDanielsen, Børsheim \& Oma, 2007; Dahl, 2014, 2016a, 2016b).

\section{Et tankeeksperiment}

Framfor å trekke fram et kulturminnefelt i beitemark og argumentere for behov for sjakting og avdekking, 
Fig. 4. Oversikt over påviste bruksfaser på Myklebust. Illustrasjon: Theo G. Bell, AM, UiS. Fig. 4. The different phases in Myklebust. Illustration: Theo G. Bell, AM, UiS.

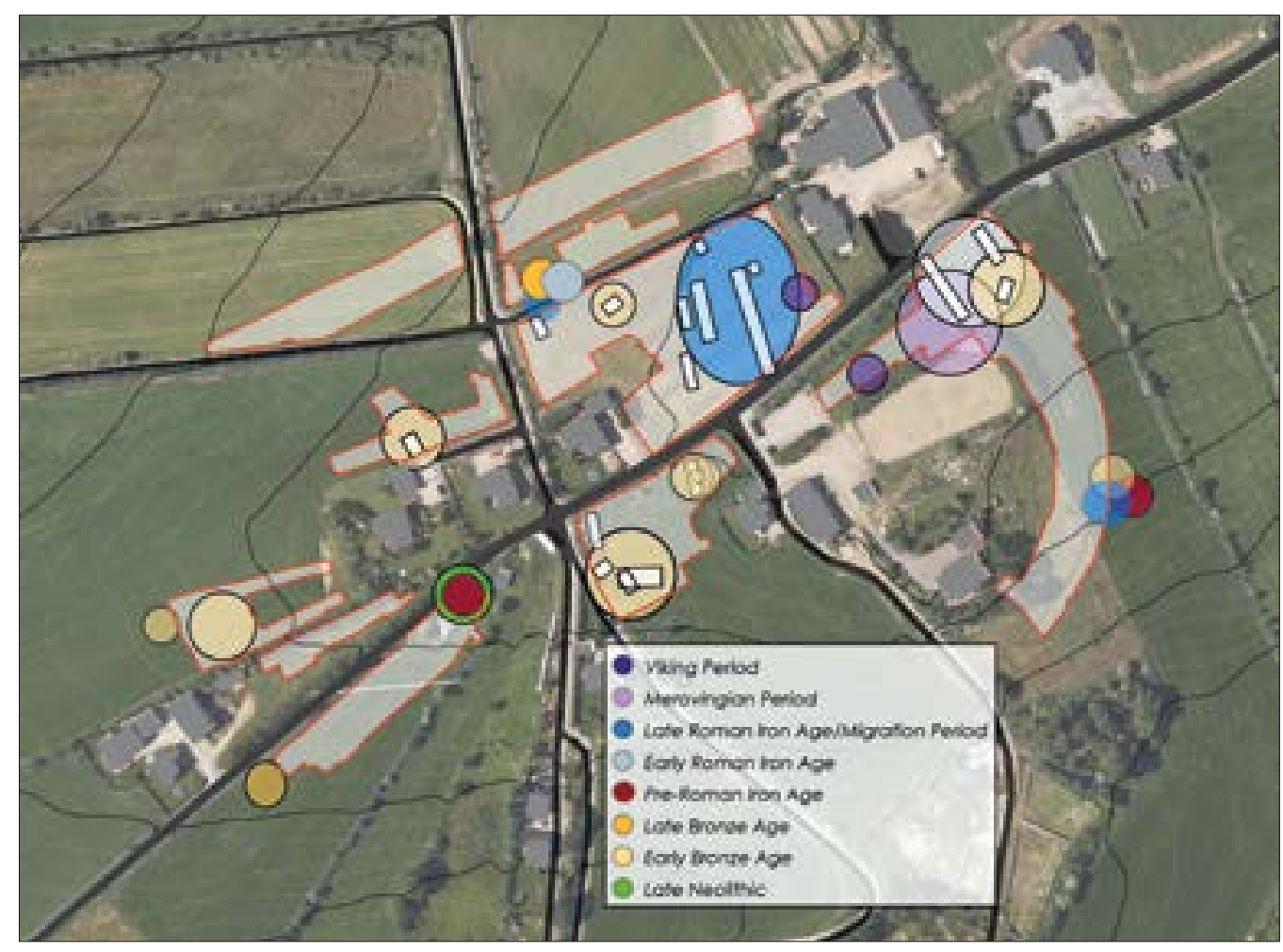

kan utgravinga på Myklebust benyttes som et tankeeksperiment. Undersøkelsesområdet utgjør vestlig del av en markant høyderygg ved innløpet til Hafrsfjord i Sola kommune (Dahl, 2014, 2016b). Østlig del av undersøkelsesområdet karakteriseres av fulldyrka mark avgrensa av enkelte spredte boliger. Myklebustveien følger høydedragets topp øst-vest og deler inn undersøkelsesområdet i ei nordvendt og ei sørvendt helling. Vestlig del av planområdet har ei svak helling ned mot ei karrig, småkupert kystlinje. Denne delen av Myklebust besto tidligere av beitemark som ble maskinelt oppdyrka i etterkrigstida. Et lite område rundt ei stor flyttblokk, Alvasteinen, ble imidlertid skånet fra den maskinelle oppdyrkinga.
Utgravinga i 2010 og 2011 påviste bosettingsspor spredt over et stort område, men med en klar fortetting til østlig del av undersøkelsesområdet.

Bevaringsforholdene var svært vekslende, fra bygninger som kun hadde bevarte spor etter takbærende stolpehull til bygninger med rester av gulvlag og stor detaljrikdom. Bygningene har en spennvidde i alder fra eldste bronsealder til og med folkevandringstid. I tillegg ble det undersøkt to områder, omtalt som aktivitetsområder, der det ikke ble påvist erkjennbare spor etter grindbygde hus. De to aktivitetsområdene er datert til seinneolitikum og vikingtid (se Fig. 4 og 5). I tillegg ble det funnet spredte kokegroper vest i planområdet som er datert til eldre og yngre bronsealder.

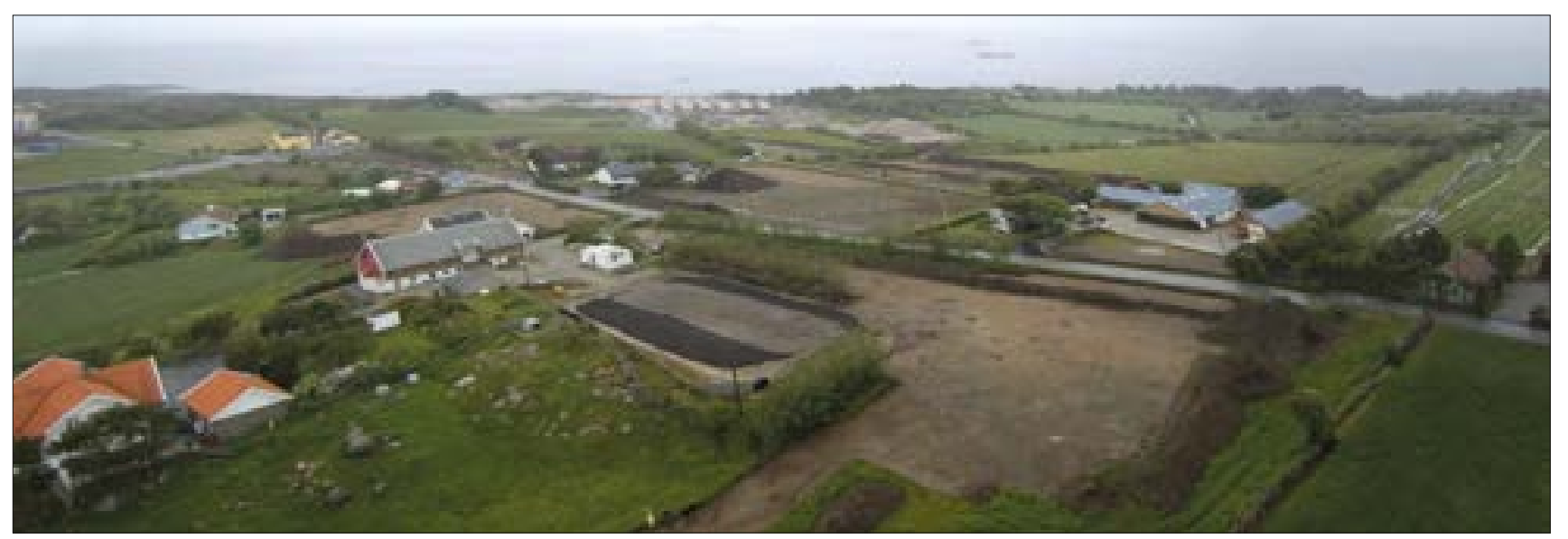

Fig. 5. Utgravingsfeltene på Myklebust var lokalisert til dyrkamark mellom moderne bebyggelse. Foto: Espen Torp, Birdy AS. Fig. 5. The excavation areas in Myklebust were situated in farmed fields surrounded by modern buildings. Photo: Espen Torp, Birdy AS. 


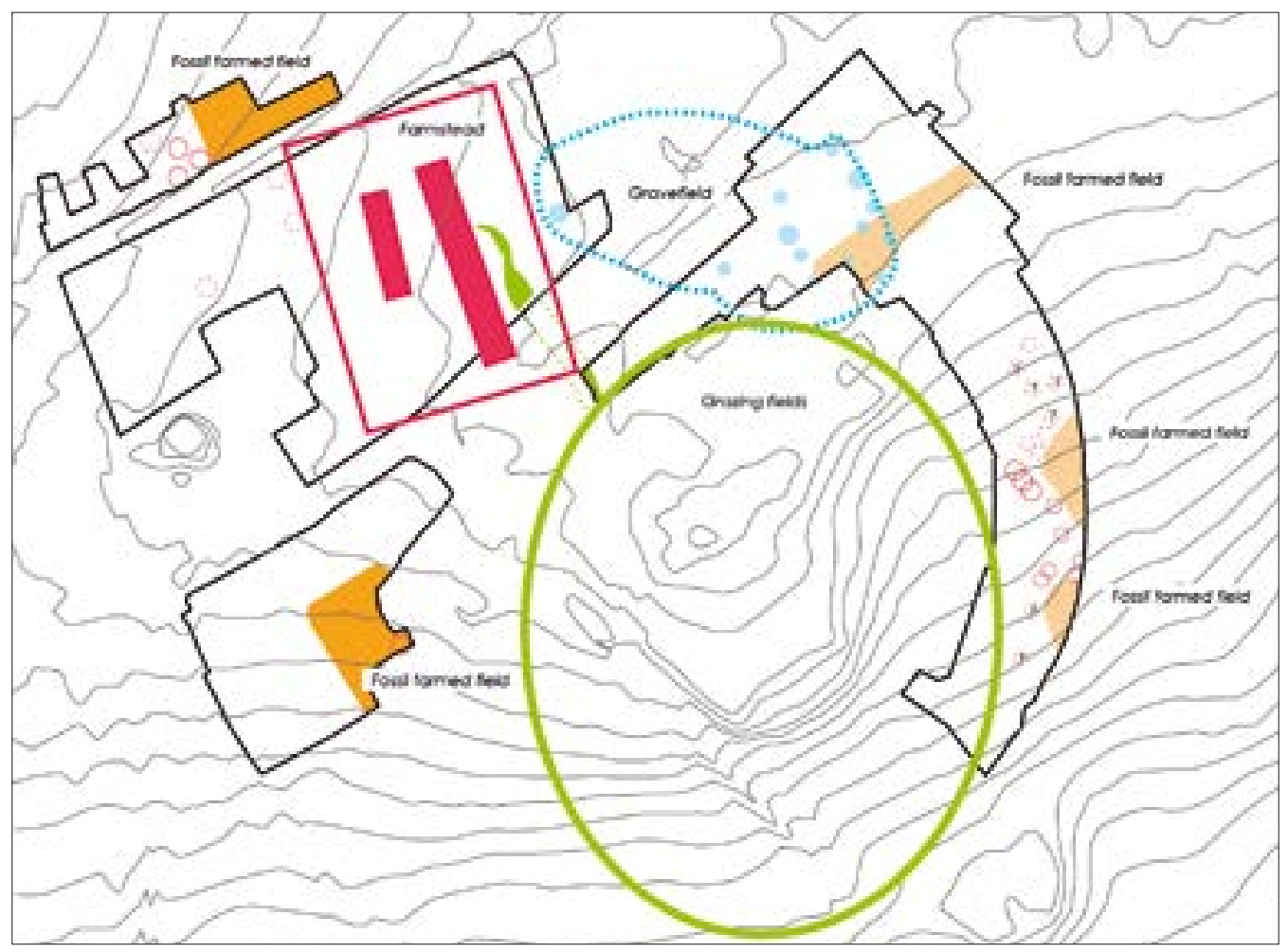

Fig. 6. Mulig tolkning av et gardsanlegg på Myklebust. Illustrasjon.: Theo G. Bell, AM, UiS. Fig. 6. A possible interpretation of a prehistoric farm complex at Myklebust. Illustration.: Theo G. Bell, AM, UiS.

Det ble utelukkende påvist bevarte spor etter graver fra yngre jernalder, alle samlet til den østligste delen av undersøkelsesområdet. Mens den velutrusta begravelsen fra vikingtid lå godt skjermet fra moderne pløying 60 $\mathrm{cm}$ ned i undergrunnen, framsto gravene fra merovingertid som langt mer forstyrret av moderne aktiviteter. Det ble funnet rester etter rydningsrøyser både i den sørvendte hellinga og under et steingjerde i den langt slakere hellinga mot nord. Makrofossil- og pollenanalyser gir innblikk i avsviing, rydding, åker- og beitebruk fra seinneolitikum til og med folkevandringstid.

Vi kan stille oss selv spørsmål om hva vi ville ha registrert og gravd på Myklebust hvis alt var beitemark, og vi unnlot å sjakte og avdekke. Ei tenkt registrering i beitemark på Myklebust ville høyst sannsynlig ha fanget opp aktivitetsområdet fra seinneolitikum og førromersk jernalder inntil den store flyttblokka Alvasteinen (Fig. 4 og 5). Den høye graden av sannsynlighet for at vi ville fått innblikk i denne interessante bruken av landskapet ligger i valg av registreringsmetode siden vi har tradisjon for å anvende prøvestikk i beitemark.

Den 42 m lange hovedbygningen fra yngre romertid/ folkevandringstid ville kun ha blitt registrert hvis den hadde bevarte ytre steinvegger, synlige på markoverflata. Synlige tufter ville trolig lagt sterke føringer for vår tolking av hele høydedraget, der alle andre synlige kulturminner ville blitt tolket inn i en gardsanleggkontekst (Fig. 6). Det er vanskelig å ikke la det monumentale dominere blikket fullstendig, enten det er bygninger eller gravanlegg. Uten omfattende sjakting og avdekking ville det ikke vært mulig å fange opp de mange spredte bygningene fra bronsealder og eldre jernalder. De mindre bygningene på Myklebust kan belyse utfordringer knyttet til materialets representativitet. På lokaliteter med store mengder anleggsspor må det foretas strenge prioriteringer både med hensyn til utgravingsomfang og dateringer. Store bygninger prioriteres ofte på bekostning av mindre bygninger, og i studier av forhistorisk byggeskikk er det gjerne de store langhusene som står i fokus. Underkommuniseringa av mindre bygninger kan være svært utslagsgivende for bildet av perioder der små hus kan være overrepresentert i forhold til de større, mer typologisk gjenkjennbare bygningene (Løken, 1998, s. 108; Dahl, 2014, s. 72). De fortidige praksisene utspilte seg imidlertid ikke kun under tak. Vi kan se for oss ulike uterom, deriblant gardsrom mellom og utenfor bygninger som på Myklebust var preget av svært mange kokegroper og avfallsgroper med keramikk av en karakter som ellers gjerne assosieres med gravkontekster (Kristoffersen \& Magnus, 2010, s. 11; Dahl, 2014, s. 107-113).

På toppen av høydedraget ble det funnet anlegg tolket som rester etter røyser (Dahl, 2014, s. 176, Fig. 7). Det holdes som sannsynlig at gravene fra yngre jernalder kan ha vært dekket av røys eller haug fjernet ved oppdyrking av området (Dahl, 2014, s. 201). Hvis hovedbygningen fra yngre romertid/folkevandringstid hadde hatt ytre steinvegger, synlige på markoverflata, 
Fig. 7. Gravfeltet fra merovingertid på Myklebust. Illustrasjon: Theo G. Bell, AM, UiS. Fig. 7. The grave field from the Merovingan Period at Myklebust. Illustration: Theo G. Bell, AM, UiS.

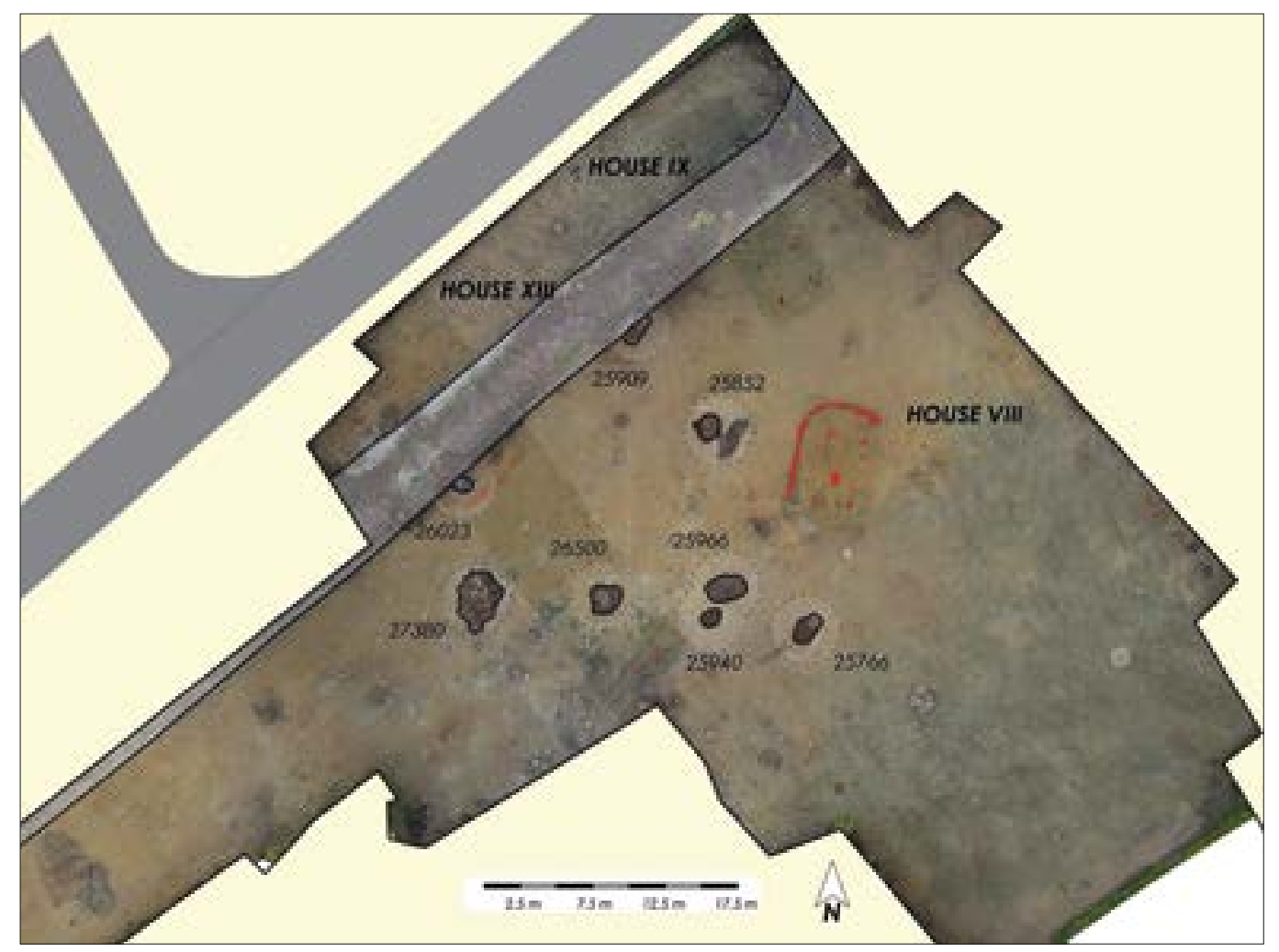

ville røyser i nærområdet ha blitt tolket som del av et gardsanlegg fra samme periode. Uten ei synlig hustuft er det stor sannsynlighet for at lokaliteten ville bli tolket som et røysfelt. Hvis vi ser for oss små røyser over gravgjemmene fra yngre jernalder, er det en mulighet for at røysene ville ha blitt tolket som rydningsrøyser. En slik tolking forsterkes ved at det finnes rydningsrøyser lenger nede i hellinga, og ved overflateregistrering er gjerne vår første tolking at det er tale om én kategori kulturminner fra én periode. Det er høyst usannsynlig at de lave røysene ville bli tolket som et gravfelt fra merovingertid uten omfattende avdekking og utgraving. Mange av gravene funnet på Myklebust ville trolig ikke vært synlige på markoverflata. Hvis vi trekker inn de bevarte gardsanleggene i beitemark, burde vi ha hatt gravene tilhørende bygningene fra yngre romertid/folkevandringstid innenfor en radius på $50 \mathrm{~m}$. At gravene ikke er der i dyrkamark, betyr ikke at vi kan konkludere med at de aldri har vært der. Det bør ikke være slik at det ene utelukker det andre, at vi i dyrkamark har bosetting, og kun gravgjemmer nedgravd i undergrunnen, mens vi i beitemark har røyser, og kun bosetting synlig på dagens markoverflate. Så lenge vi vegrer oss for sjakting og avdekking, finner vi ikke noe mer heller. Vi blir med andre ord låst $i$ egen praksis.

\section{Langtidsperspektiv}

Dateringene fra Myklebust viser lang tids bruk av høydedraget (Fig. 8). I denne sammenhengen kan det være fruktbart å nevne modernismens lineære tid som et annet sentralt element innenfor vår praksis. Langtidsperspektivet, som holdes fram som en sentral styrke innenfor museumsfag, sporer oss gjerne inn på en lineær framstilling der tida stykkes opp i arkeologiske perioder som avløser hverandre (Olsen, Shanks, Webmoor \& Witmore, 2012, s. 136). Ved arkeologiske undersøkelser betraktes tidfesting av ulike hendelser som det sentrale grep vi benytter for å organisere de sammensatte sporene vi finner innenfor undersøkelsesområdet. Vår praksis preges sterkt av kategorisering og systematisering, inn i stadig finere, daterte tynnslip innenfor fortellinga om forhistorien. Men det er ikke nødvendigvis gitt at sekvensene framstilles som isolerte hendelser som avløser hverandre. Langtidsperspektivet innebærer lang tids bruk og gjenbruk. Vi kan forsøke å åpne for perspektiv som ikke kun fokuserer på datering av enkelthendelser, men som vier oppmerksomhet til prosesser og ulike praksiser som viser til gjentatt bruk og omforming av landskapet (Dahl, 2016a, s. 77, 93). De sammensatte lokalitetene har sin styrke og store vitenskapelige potensial nettopp i de varierte sporene som kunne tas i bruk i nye sammenhenger i nye forhistoriske praksiser. Sammenblandet og kompleks, mer som den kaotiske helheta som møter oss arkeologer når vi starter ei utgraving, kan fortelle mer om fortidige levde liv enn et narrativ med atskilte, daterbare sekvenser. 
OxCal v4.1.7 Brock Ramsey (2050), r.5. Amoscheric dna from Reiner of w (2009)

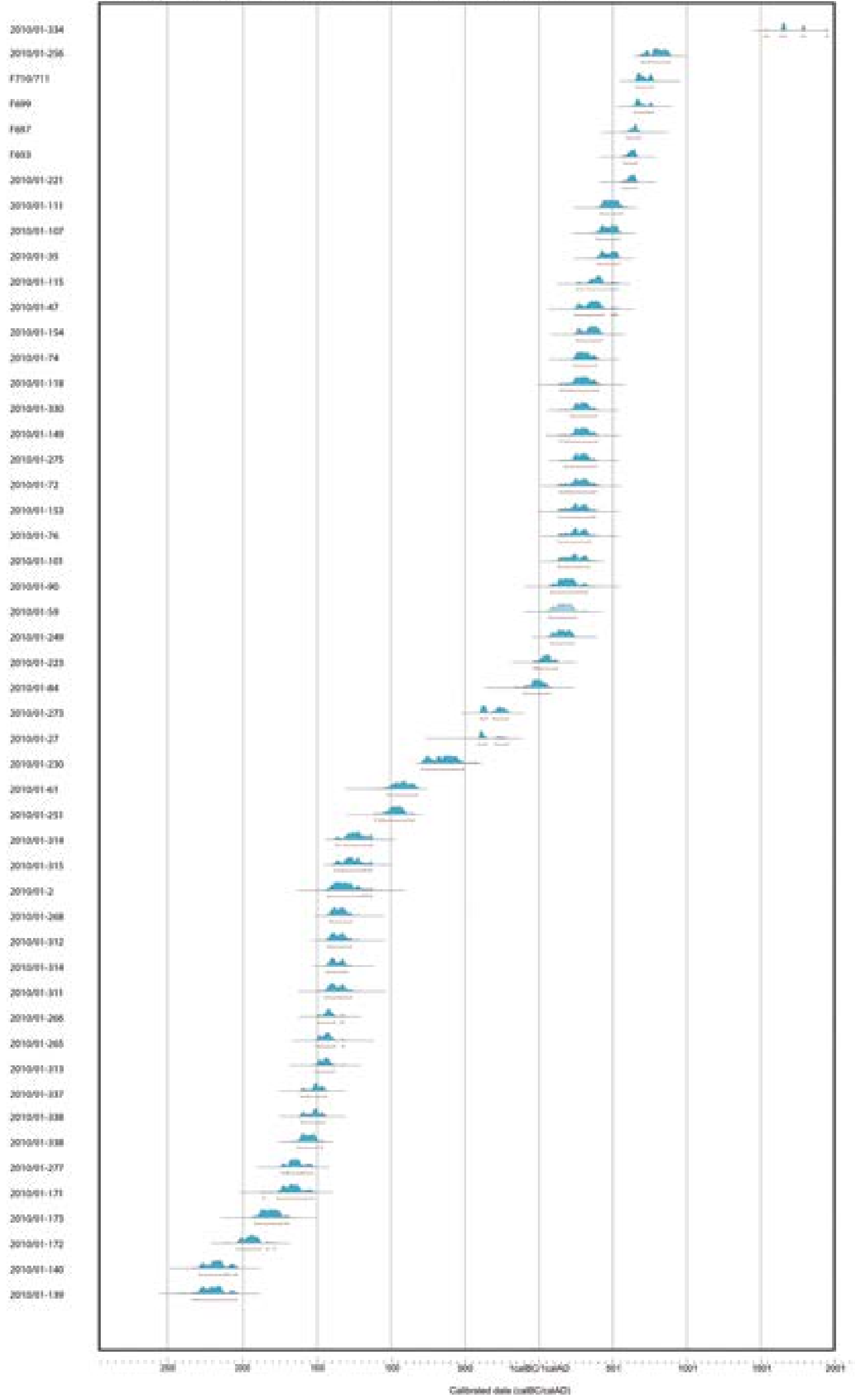

Fig. 8. De radio-

logiske dateringene

fra Myklebust.

Fig. 8. The radio-

carbon dates from

Myklebust. 


\section{Feltpraksis}

Det kan være vanskelig å endre innarbeida tankesett, men det er håp om at feltpraksis kan benyttes til å skape bevegelser i seige strukturer. Feltpraksis fordrer åpenhet og fleksibilitet for å kunne oppdage nye fenomener og relasjoner (Lucas, 2001; Lönn \& Petersson, 2013). Vi må være forberedt på overraskelser underveis i utgravinger og utvikle strategier for hvordan vi kan håndtere det ukjente slik at det ikke overses, nedprioriteres eller tolkes inn i noe allerede familiært (Lönn \& Petersson, 2013, s. 692). Kontinuerlige nyoppdagelser bør løftes fram som det vesentlige moment ved feltarbeid, og for å unngå at utgravinger blir en selvoppfyllende praksis, kan vi fokusere på det som ikke nødvendigvis passer inn i våre systemer (Lucas, 2001, 42). I forlengelsen av denne argumentasjonen ligger balansegangen mellom det generelle og det spesielle i kjernen av kunnskapsproduksjonen ved ethvert feltarbeid.

Til tross for at feltpraksis er en uløselig del av kunnskapsproduksjonen, blir denne delen av vår virksomhet i for liten grad diskutert i Norge (Brun, 2017, s. 189). En større kritisk bevissthet om feltprosedyrer hører med i de videre teoretiske diskusjonene (Lucas, 2001, s. 39; Olsen et al., 2012, s. 53; Lönn \& Petersson, 2013, s. 685; Brun, 2017, s. 190). Det er ønskelig med et økt fokus på utgravingers rolle i arkeologisk kunnskapsutvikling (se Iversen \& Petersson, 2016, s. 9). Forvaltningsundersøkelser betraktes som fundamentet for universitetsmuseenes samfunnsansvar og som uvurderlige generatorer for arkeologisk forskning og formidling. Ved å plassere forvaltningsundersøkelser og feltpraksis i sentrum av vår kunnskapsutvikling, er det muligens via feltpraksis det er enklest å åpne perspektivet, for det er nettopp et videre perspektiv bruk av maskin byr på. Ved å betrakte maskin som nødvendig utstyr gjennom hele felt- og registreringsarbeidet, kan vi skape en viktig motvekt til frimerketenking rundt synlige kulturminner, da de konstruerte enkeltminner vil kunne få kontekster. Vi snakker ellers om teoretiske verktøykasser, men hvis metode og feltpraksis kan representere alternative ruter, bør vi utstyre verktøykassa med en maskin snarest.

\section{Summary}

Discussions of the ways methodology shapes our knowledge of the past should be an ongoing, central exercise within archaeology. Currently, surveys and excavations of cultivated areas vs. pasture areas follow two diverging trajectories: cultivated areas are surveyed and excavated by top soil stripping whereas pasture areas are surveyed by test pits and thereafter by excavations of visible features. The essential question of source criticism when excavating cultivated land has to address the kinds of evidence we can expect to find preserved. Sites in undeveloped pasture areas represent an expedient context for evaluating the material from cultivated fields. Excavations in such areas have revealed finds that were not visible on the surface and demonstrate that surveys in pasture areas cannot be limited to evidence visible on the surface, lest we end up with two different sets of knowledges, where the modern use of the survey area defines the methodology and thus the archaeological record. Therefore, we must think beyond what is immediately visible when surveying pasturelands, and at the same time consider what we might be missing in cultivated fields. The extensive use of mechanical excavators in pasture areas is here presented as an effective means of bridging this gap. Such a methodological change can broaden our understanding of the complexity, time-depth and re-use that may be the key significance of these sites. Fieldwork involves bringing to light new objects, new matter and new knowledge (Lucas, 2001, s. 42), and could be the appropriate arena in which to encounter and challenge our perspectives on both past and present practices.

\section{Referanser}

Bennett, A. (1985). Karleby och Gärtuna. Bebyggelse och gravar från bronsålder och järnålder i Östertälje socken Södermanland. Riksantikvarieämbetet Rapport UV 1984:29. Stockholm: Riksantikvarieämbetet och Statens historiska museer.

Bennett, A. (1988). Arkeologiska undersökningar. Riksantikvarieämbetets arkeologiska undersökningar i samband med markexploatering. Forskningsförutsättningar och forskningsbehov - en pilotstudie över 25 års verksamhet. Forsking för kulturminnesvård 2. Stockholm: Riksantikvarieämbetet.

Brun, W. (2017). Når materiell kultur blir digital - ei viktig vending i norsk arkeologi. Viking, Norsk Arkeologisk Årbok, LXXX, 181-202.

Børsheim, R. L. \& Soltvedt, E. -C. (2002). Gausel-utgravingene 1997-2000. AmS-Varia 39, Stavanger: Arkeologisk museum i Stavanger.

Dahl, B. I. (2014). Arkeologisk utgraving av hus og graver. Myklebust gnr. 3, Sola kommune, Rogaland. Oppdragsrapport 2014/20. Stavanger: Arkeologisk museum, UiS.

Dahl, B. I. (2016a). Haugen som gravfelt. I W. Brun \& E. S. Pedersen (Red.), Tverrfaglige perspektiver 3, AmS-Varia 58, s. 77-96. Stavanger: Arkeologisk museum, UiS.

Dahl, B. I. (2016b). Relations between burials and buildings in the Iron Age of Southwest Norway. I F. Iversen \& H. Petersson (Red.), The Agrarian life of the North 2000 $B C-A D$ 1000: Studies in rural settlement and farming in Norway, s. 93-116. Kristiansand: Portal.

Iversen, F. \& Petersson, H. (Red.).(2016). The Agrarian life of the North 2000 BC-AD 1000: Studies in rural settlement and farming in Norway. Kristiansand: Portal.

Kristoffersen, S. \& Magnus, B. (2010). Spannformete kar. Utvikling og variasjon. AmS-Varia 50. Stavanger: Arkeologisk museum, UiS.

Lucas, G. (2001). Destruction and the Rhetoric of Excavation. Norwegian Archaeological Review 34, 1, s. 35-46.

Løken, T. (1992). Ullandhaug sett i lys av Forsandundersøkelsene. I A. K. Skår (Red.), Gammel gård gjenoppstår, AmS-Småtrykk 26, s. 31-46, Stavanger: Arkeologisk museum i Stavanger. 
Løken, T. (1998). Hustyper og sosialstruktur gjennom bronsealder på Forsandmoen, Rogaland, Sørvest-Norge. I T. Løken (Red.), Bronsealder i Norden - Regioner og interaksjon. Foredrag ved det 7. nordiske bronsealdersymposium $i$ Rogaland 31. august-3. september 1995, AmS-Varia 33, s. 107-121. Stavanger: Arkeologisk museum i Stavanger.

Lönn, M. \& Petersson, H. (2013). Construction archaeology, fieldwork and theory. I S. Bergerbrant \& S. Sabatini (Red.), Counterpoint: Essays in Archaeology and Heritage Studies in Honour of Kristian Kristiansen. BAR International Series 2508, s. 685-693. Counterpoint Oxford: Archaeopress.

Myhre, B. (1980). Gårdsanlegget på Ullandhaug 1. Gårdshus i jernalder og tidlig middelalder $i$ Sørvest-Norge. AmSSkrifter 4. Stavanger: Arkeologisk museum i Stavanger. Olsen, B., Shanks, M., Webmoor, T. \& Witmore, C. (2012). Archaeology: The discipline of Things. University of California Press, Berkeley.

Soltvedt, E.- C., Løken, T., Prøsch-Danielsen, L., Børsheim, R. L. \& Oma, K. (2007). Bøndene på Kvålehodlene. Boplass-, jordbruks- og landskapsutvikling gjennom 6000 år på Jeren, SV Norge. AmS-Varia 47. Stavanger: Arkeologisk museum i Stavanger.

Wangen, V. (1999). Gravfeltet på Gunnarstorp. I Et monument over dødsriter og kultutøvelse. Magistergradsavhandling. Universitetet i Oslo. 